with their condition. Patients thought telling others about improved well-being and that there was much to gain from PR and nothing to lose would encourage others to participate. This new information could be used to stimulate patient engagement.

\begin{tabular}{|c|c|}
\hline \multicolumn{2}{|c|}{ Question 1: What were the most useful aspects of the course? } \\
\hline Main Theme & Example \\
\hline 1. Exercise and Improvements in Fitness & $\begin{array}{l}\text { "The use of the weights. Better breathing, } \\
\text { walking" }\end{array}$ \\
\hline 2. Motivation to exercise & $\begin{array}{l}\text { "Encouragement to exercise especially } \\
\text { walking more" }\end{array}$ \\
\hline $\begin{array}{l}\text { 3. Learning and gaining information } \\
\text { through the Education sessions. Gaining } \\
\text { coping skills. }\end{array}$ & $\begin{array}{l}\text { "Learning about lung disease, how to cope } \\
\text { with it. Getting information which I should } \\
\text { have been given years ago. Also knowing } \\
\text { what other options there are." }\end{array}$ \\
\hline $\begin{array}{l}\text { 4. Increasing confidence to self- } \\
\text { manage. }\end{array}$ & $\begin{array}{l}\text { "Giving me confidence to deal with the } \\
\text { problem." }\end{array}$ \\
\hline 5. Importance of the Role of Healthcare & "Having someone there to encourage you to \\
\hline Professionals & push your limits while still feeling safe." \\
\hline $\begin{array}{l}\text { 6. Meeting other patients with similar } \\
\text { conditions }\end{array}$ & $\begin{array}{l}\text { "Meeting people with the same condition } \\
\text { and realising how lucky I am and enjoying } \\
\text { their company." }\end{array}$ \\
\hline
\end{tabular}

Question 2: Do you have a comment that we could use for promotion of the program which would encourage other patients to participate?

Main Theme and Sub Themes
1. Wellbeing
I. Coping with condition
II. Meeting similar others
III. Increase in Confidence
IV. Improved fitness

Example

I. "The course is very beneficial in many ways with breathing, walking, strength and education talks and it helps you to cope with your illness."

"It is well worth doing as it has helped me very much with my life."

II. "It is inspiring to meet people with similar problems."

III. "Increased my confidence in walking +being more active."

IV. "The course has encouraged me to be more active and progress on to the next level to improve my fitness."

"If you get the chance to take part in this course - 'go for it' it can only do good."

\section{P77 SHUTTLE WALK TESTS: ARE THEY JUST AN OUTCOME MEASURE?}

P Kanabar, J Ruksenaite, L Houchen-Wolloff, S Singh. Centre for Exercise and Rehabilitation Science, University Hospitals of Leicester NHS Trust, Leicester, UK

\subsection{6/thoraxjnl-2017-210983.219}

Introduction Exercise tests are a keystone in assessing patients for Pulmonary Rehabilitation (PR). Behavioural research has suggested that performing an outcome measure may influence the outcome. ${ }^{1}$ This has not been explored in respiratory disease in relation to performing an exercise test. Performing an exercise tests could improve confidence and alter subsequent exercise behaviour.

Aim To assess if completing a single incremental shuttle walk test (ISWT) increases patients' confidence in walking at home; managing breathlessness, or completing a shuttle walk test.
Methods Patients attending a PR assessment were asked to score their confidence levels according to the above criteria prior to their first ISWT, and then again following their $1 \mathrm{st}$ ISWT. Patients answered the following questions before and after completing an ISWT with regards to their confidence in the following conditions: 1)Walking at home(Q1), 2)Managing breathlessness(Q2), and 3)Completing the ISWT(Q3). All questions were graded on a VAS scale of $0-10$.

Results 90 patients (Mean age- 68.51 years; 48 Males; FEV1$1.46 \mathrm{~L}$; MRC median- 3) with respiratory disease answered the questions. There were statistically significant differences in confidence pre and post ISWT in all 3 questions $(\mathrm{p}=0.00)$. Pre-ISWT the values were (Q1) 5.74, (Q2) 6.25, (Q3) 7.07, the mean changes were: (Q1) +1.51; (Q2) +0.92; (Q3) +1.13 points. No significant changes in distance covered in the second ISWT were noted $(21.2 \mathrm{~m})$. There was no correlation between the change in confidence and change in distance covered between the two tests $\left(r^{2}=(\mathrm{Q} 1)\right.$ 0.001, (Q2) 0.003, (Q3) 2.50, $\mathrm{p} \geq 0.05$ )

Conclusion Performing the ISWT increased patients' perceived confidence levels to manage their breathlessness and walking at home. This may have implications when designing clinical trials particularly in the control group where the performance of an ISWT may alter exercise behaviours. Further research is required to investigate the effects of completing outcome measures in clinical trials.

\section{REFERENCE}

1. Godin et al. The Effect of mere-measurement of cognitions on physical activity behaviour: A randomised controlled trial among overweight and obese individuals. International Journal of Behavioural Nutrition and Physical Activity 2011;8:2.

\section{P78 CARDIOVASCULAR AND MUSCULOSKELETAL PHENOTYPES AND THE CLINICAL OUTCOMES IN COPD: A SYSTEMATIC REVIEW AND META-ANALYSIS}

${ }^{1} \mathrm{JM}$ Fermont, ${ }^{1} \mathrm{KL}$ Masconi, ${ }^{1} \mathrm{AM}$ Wood, ${ }^{2} \mathrm{H}$ Müllerova, ${ }^{1} \mathrm{IB}$ Wilkinson. 'University of Cambridge, Cambridge, UK; ${ }^{2}$ GlaxoSmithKline R\&D, Uxbridge, UK

\subsection{6/thoraxjnl-2017-210983.220}

Systematic reviews examining the relationship between cardiovascular and musculoskeletal phenotypes and relevant clinical outcomes in chronic obstructive pulmonary disease (COPD) are currently lacking. We have systematically summarised and examined the predictive value of selected phenotypes that could be utilised in clinical practice. We identified 61 cohort studies with longitudinal data collection. Meta-analysis indicated that the $6 \mathrm{~min}$ walking distance (6 MWD; HR 0.83, 95\% CI 0.79 to 0.87 ), resting heart rate (HR 1.09, 95\% CI 1.02 to 1.15 ), C-reactive protein ( $\mathrm{HR} 1.24$, 95\% CI 1.08 to 1.40), fibrinogen ( $\mathrm{HR}$ 4.18, 95\% CI 1.13 to 7.22 ) and tumour necrosis factor-alpha (HR $0.91,95 \%$ CI 0.82 to 1.00 ) were independent predictors of clinical outcomes in stable COPD patients, after adjusting for sex, age, body mass index and smoking status. Very few studies examined the association between musculoskeletal phenotypes such as the short physical performance battery, quadriceps maximum voluntary contraction, and sniff nasal inspiratory pressure and clinical outcomes in COPD. With the limited adoption of the $6 \mathrm{MWD}$ in clinical practice there is a need for faster and simpler tests to identify COPD patients at an increased risk for adverse events in an early stage of disease. 